\title{
Use of edible insects in thermal-induced protein gels containing porcine myofibrillar
}

\section{protein}

\author{
T.-K. Kim ${ }^{1 \#}$, M.H. Lee ${ }^{2 \#}$, J.Y. Cha ${ }^{1}$, J. Kim ${ }^{1}$, M.-C. Kang' ${ }^{1}$, H.I. Yong ${ }^{1}$, S. Jung ${ }^{2}$ and Y.-S. Choi ${ }^{1 *}$ i \\ ${ }^{1}$ Research Group of Food Processing, Korea Food Research Institute, Wanju 55365, Republic of Korea; ${ }^{2}$ Division of Animal \\ and Dairy Science, Chungnam National University, Daejeon 34134, Republic of Korea; kcys0517@kfri.re.kr; ${ }^{\#}$ these authors \\ contributed equally to this work
}

Received: 26 September 2021 / Accepted: 12 November 2021

(c) 2022 Wageningen Academic Publishers

OPEN ACCESS CC $\underset{\mathrm{BY}}{(i)}$ RESEARCH ARTICLE

\begin{abstract}
Edible insects are considered an environmentally friendly source of protein; however, products containing only edible insects are associated with poor quality and processing properties. Therefore, we examined and compared the thermal stability and rheological properties among thermal-induced myofibrillar protein gels prepared using porcine myofibril protein and five different edible insect species: larvae: Tenebrio molitor L., Protaetia brevitarsis, and Allomyrina dichotoma and adult insects: Gryllus bimaculatus and Oxyachinensis sinuosa. The myofibrillar protein gels containing edible insects had a higher $\mathrm{pH}$ than that of the control. The water-holding capacity of the myofibrillar gel containing G. bimaculatus (T4) was higher than that of the other samples. The hardness, cohesiveness, gumminess, and chewiness of the thermal-induced myofibrillar gel containing T4 were the highest. The myofibrillar gel containing edible insects had a higher peak temperature than that of the control, except for $\mathrm{T} 4$, as well as a similar or lower enthalpy, which is required for denaturation. All myofibrillar gels with/without edible insects exhibited Hershel-Bulkley fluid properties, and rigid structures were developed during heating. The myofibrillar protein gels containing T4 revealed excellent processing properties. Therefore, myofibrillar protein gels containing T4 may be used for producing protein-rich foods.
\end{abstract}

Keywords: thermal-induced gel, myofibrillar protein, edible insect, thermal stability, rheological property

\section{Introduction}

Myofibrillar protein is considered an important protein owing to its gel-forming ability in meat protein (Kim et al., 2021a), and it affects the processing of emulsion meat products (McCord et al., 1998). Myofibrillar proteins comprise approximately $60 \%$ of total meat protein (Choi et al., 2011) and play an important role in improving functional properties of meat foods such as gel-forming ability, water-binding ability, and emulsifying properties (Li et al., 2020). It is well known that myofibrillar protein, a salt-soluble protein, forms a gel via thermal denaturation, and this protein gel has a stable three-dimensional network structure (Choi et al., 2011). The myofibrillar protein gel network structure depends on the protein concentration, $\mathrm{pH}$, and actomyosin solubility (Yasui et al., 1982). Xu and $\mathrm{Xu}$ (2021) reported that myofibrillar proteins are primarily responsible for processing yield, texture properties, and organoleptic characteristics of emulsion meat products. Few studies have reported a new approach to improve the functional properties of myofibrillar proteins with addition of polyphenols or polysaccharides (Cheng et al., 2020; Zhuang et al., 2020). However, the addition of non-protein fraction such as polyphenols or polysaccharides could increase the processing cost or decrease protein nutritional value in essential amino acid. Therefore, other approach should be conducted to improve functional properties of myofibrillar protein.

Edible insects are considered as a food source as they provide food security (Kim et al., 2021a); studies have additionally evaluated insect proteins as an alternative to animal protein (Kim et al., 2019a). Edible insect protein is an environmentally friendly protein since its production 
can reduce environmental pollution compared to that created by animal protein production (Köhler et al., 2019). Additionally, production of edible insect protein is effective in maintaining carbon neutrality, as it can reduce carbon dioxide emissions (Ham et al., 2021). However, edible insect proteins are associated with technical limitations and cannot completely replace animal protein at present (Choi et al., 2017). Kim et al. (2019b) reported that a product containing only edible insects results in poor quality and processing properties. Edible insect processing technologies are currently under research to overcome technical limitations (Kim et al., 2021a; Park et al., 2017). Thus, this study investigated and compared the properties between porcine myofibrillar proteins and edible insect proteins. The aim of this study was to evaluate and compare the physicochemical properties of thermal-induced protein gels between porcine myofibril and edible insect proteins obtained from different insect species to enhance their rheological properties.

\section{Materials and methods}

\section{Porcine myofibrillar protein extraction}

Porcine myofibrillar protein extraction was performed as described by Choi et al. (2011). The freeze-dried porcine myofibrillar protein was prepared as below method. Firstly, fresh pork ham (M. biceps femoris, M. semitendinosus, and M. semimembranosus) was obtained from local market A and ham was ground through $8 \mathrm{~mm}$ grinder. To dissolve sarcoplasmic protein, one parts of ground meat was dissolved in 4 parts of $0.1 \mathrm{M} \mathrm{KCl}$ in $0.01 \mathrm{M}$ phosphate buffer at $\mathrm{pH} 7.4$. After centrifuging at $15,000 \times \mathrm{g}$ using continuous centrifuge (HC-140HO, Hanil SME, Anyang, Korea) collected residue was re-dissolved in 4 times of 0.1 $\mathrm{M} \mathrm{KCl}$ in $0.01 \mathrm{M}$ phosphate buffer. Same procedure was repeated 2 times and lastly, remained salt was removed by distilled water using continuous centrifuge ( $\mathrm{HC}-140 \mathrm{HO})$. Residue was considered as myofibrillar protein (MP) and freeze-dried MP was dissolved in $0.58 \mathrm{M}$ saline solution at $30 \mathrm{mg} / \mathrm{ml}$.

\section{Preparation of edible insects}

The larvae of three insects (Tenebrio molitor L., Protaetia brevitarsis, and Allomyrina dichotoma) and two adult insects (Gryllus bimaculatus and Oxyachinensis sinuosa) commonly used in industrial applications were selected. An important factor in selecting edible insects is whether they can be used easily as well as for industrial use. Edible insects were purchased from Farm Bang (Suncheon, South Korea). The fasting insects were obtained and stored at $-15{ }^{\circ} \mathrm{C}$. The insects were freeze-dried and pulverised to obtain an insect powder. Pulverised insects were filtered through a sieve (20 mesh) and used for preparation of myofibrillar protein gels.

\section{Gel preparation}

Thermal-induced myofibrillar gel was prepared as described by Choi et al. (2011). To prepared mixed gel, $1 \%$ of insect powder was added into $30 \mathrm{mg} / \mathrm{ml}$ of myofibrillar protein gel. Control was prepared without any edible insect. The insect species which added in myofibril gel were T. molitor larvae, P. brevitarsis larvae, A. dichotoma larvae, G. bimaculatus adult, $O$. sinuosa adult and treatments named T1, T2, T3, $\mathrm{T} 4$, and $\mathrm{T} 5$ in order. The mixed porcine myofibril protein and edible insects were transferred into $20 \mathrm{~mm}$ diameter glass gelling tubes. The gel solution containing porcine myofibrillar protein and edible insects was centrifuged at $800 \times g$ for $10 \mathrm{~min}$ to remove air bubbles $\left(4^{\circ} \mathrm{C}\right)$. The sealed tubes containing the gel solution were heated at $75^{\circ} \mathrm{C}$ for $30 \mathrm{~min}$.

\section{pH}

The $\mathrm{pH}$ values of the non-thermal and thermal-induced myofibrillar gel containing edible insect samples were measured in a mixture comprising $5 \mathrm{~g}$ of sample and 50 $\mathrm{ml}$ distilled water $20 \mathrm{ml}$ using a $\mathrm{pH}$ meter.

\section{Colour}

The lightness $\left(\mathrm{L}^{*}\right)$, redness $\left(\mathrm{a}^{*}\right)$, and yellowness $\left(\mathrm{b}^{*}\right)$ values of the non-thermal and thermal-induced myofibrillar gel containing edible insect samples were measured (Illuminant C) using a colourimeter (CR-410; Minolta Co., Osaka, Japan).

\section{Water-holding capacity}

The water-holding capacity (WHC) of the thermal-induced myofibrillar gel containing edible insect samples was determined gravimetrically as described by Kocher and Foegeding (1993). After cover $1 \mathrm{~g}$ of heat-induced gel using filter paper (No. 4, Whatman Ltd. Kent, UK), samples were centrifuged at $6,710 \times g$ for $10 \mathrm{~min}$. The difference weight of filter paper before and after centrifugation was considered as moisture loss and it was compared with protein gel weight (1). The WHC was calculated as percentage (\%).

$$
\text { WHC }(\%)=\frac{\text { Weight of sample before centrifugation }- \text { moisture loss content after centrifugation }}{\text { Weight of sample }} \times 100
$$




\section{Texture profile analysis}

The textural properties of the thermal-induced myofibrillar gel containing edible insect samples were measured using a texture analyser (TA-XT2i; Stable Micro Systems, Surrey, England) with $25.4 \mathrm{~mm}$ diameter cylinder probe. The texture profile analysis conditions were as follows: height of myofibrillar gel, $15 \mathrm{~mm}$; maximum load, $2 \mathrm{~kg}$; force, 10 g; pre-test speed, $3.0 \mathrm{~mm} / \mathrm{s}$; post-test speed, $5.0 \mathrm{~mm} / \mathrm{s}$; distance, $10.0 \mathrm{~mm}$; and head speed, $3.0 \mathrm{~mm} / \mathrm{s}$ (Bourne et al., 1978).

\section{Differential scanning calorimetry}

The thermal properties of the myofibril gels were estimated via differential scanning calorimetry (DSC; DSC 400 furnace; PerkinElmer, Waltham, MA, USA) which calibrated by indium standard. The non-heated samples (30 $\mathrm{mg}$ ) were placed in an aluminium pan and sealed tightly, and the thermal properties at $20-100{ }^{\circ} \mathrm{C}$ were evaluated based on heating at $10{ }^{\circ} \mathrm{C} / \mathrm{min}$. The onset, peak, and end temperatures were detected using Pyris data analysis software (PerkinElmer), and enthalpy $(\Delta \mathrm{H})$ was calculated using the same software (Kim et al., 2021a).

\section{Sodium dodecyl sulphate-polyacrylamide gel electrophoresis}

The protein molecular weight distribution was estimated via sodium dodecyl sulphate-polyacrylamide gel electrophoresis (SDS-PAGE) (Laemmli, 1970). All reagents and materials were obtained from Bio-Rad (Hercules, CA, USA). Protein concentration of the mixtures of MP and insect powder was regulated to $1 \mathrm{mg} / \mathrm{ml}$ solutions using bicinchoninic acid protein assay. Sample buffer and $20 \mu \mathrm{g}$ of sample was mixed and $\beta$-mercaptoethanol was used to reduce protein; Precision Plus Protein ${ }^{\text {twx }}$ Dual Color Standards (Bio-Rad Laboratories, Hercules, CA, USA) were loaded onto Mini-PROTEIN ${ }^{\bullet}$ TGXTM gels (BioRad Laboratories) after heating at $100^{\circ} \mathrm{C}$ for $5 \mathrm{~min}$. After electrophoresis at $100 \mathrm{~mA}$, the gels were stained with $0.25 \%$ Coomassie Brilliant Blue R-250 (Bio-Rad Laboratories) and destained.

\section{Evaluation of rheological properties}

The flow curves of the non-heated gel samples were characterised using a modular compact rheometer (MCR 102; Anton Paar GmbH, Graz, Austria). The measurements were performed using a parallel plate with a diameter of $25 \mathrm{~mm}$ and a gap of $1 \mathrm{~mm}$ at different shear rates ranging from $0.01-100 \mathrm{~s}^{-1}$ at $25^{\circ} \mathrm{C}$. The Herschel-Bulkley model was applied to analyse the obtained results (Gomathy et al., 2015; Štreimikytè et al., 2020), by using the following equation:
$\sigma=\sigma_{0}+K(\dot{\gamma})^{n}$

where $\sigma$ and $\sigma_{0}$ are the shear stress $(\mathrm{Pa})$ and the yield stress $(\mathrm{Pa})$, respectively; $K$ is the consistency coefficient $\left(\mathrm{Pa} " \mathrm{~s}^{\mathrm{n}}\right)$; $\dot{\gamma}$ is the shear rate $\left(\mathrm{s}^{-1}\right)$; and $n$ is the flow behaviour index.

A temperature sweep test was performed using the same equipment at a strain of $0.5 \%$ in the temperature range of $10-90{ }^{\circ} \mathrm{C}$. The storage modulus (G'), loss modulus (G'), and loss factor ( $\tan \delta=G^{\prime} / G^{\prime}$ ) were recorded using Rheocompass 1.19 (Anton Paar GmbH, Graz, Austria) during the measurements at a constant heating rate of $2{ }^{\circ} \mathrm{C} / \mathrm{min}$.

\section{Statistical analysis}

Data were obtained from triplicate experiments. All data were analysed using the general linear model procedure in SPSS (ver. 20.0; SPSS Inc., Chicago, IL, USA). The five edible insect species were considered as the main effects, and the replicates and other uncontrollable external factors were considered as randomised effects. Duncan's multiple range test was performed to investigate the significant differences between samples $(P<0.05)$.

\section{Results and discussion}

\section{$\mathrm{pH}$, colour, and water-holding capacity}

The $\mathrm{pH}$, colour, and WHC of the thermal-induced myofibrillar gel containing proteins of five different edible insect species are shown in Table 1 . The $\mathrm{pH}$ of the nonthermal and thermal-induced myofibrillar protein gels ranged from 6.13-6.51 and from 6.20-6.59, respectively. The myofibrillar protein gels containing edible insects had a higher $\mathrm{pH}$ than that of the control gels $(P<0.05)$. Kim et al. (2020) reported that the $\mathrm{pH}$ of emulsion systems replacing myofibrillar protein with $T$. molitor is significantly higher because of the high pH of T. molitor components. Similarly, the results in our study were found to be affected by the myofibrillar protein extraction buffer solution, and it is thought to be affected by the $\mathrm{pH}$ of the edible insects. These results are in agreement with those of Choi et al. (2011), who indicated that the $\mathrm{pH}$ of heated myofibrillar gel systems is higher than that of unheated myofibrillar gel systems.

The L* of the control myofibrillar gel and gel containing G. bimaculatus (T4) was higher than that of the other samples. The $L^{*}$ of the control was the highest among those of the heated samples $(P<0.05)$. When heat was applied, the $\mathrm{pH}$ tended to decrease and the $\mathrm{L}^{*}$ tended to increase. According to Choi et al. (2011), L" increases due to the scattering of water molecules when heated. The $\mathrm{a}^{*}$ and $\mathrm{b}^{*}$ of the gels containing T. molitor larvae (T2) and O. sinuosa (T5) were the highest $(P<0.05)$. This result may be due to the different colours of edible insect species (Kim et al., 
Table 1. $\mathrm{pH}$, colour, and water holding capacity (WHC) of thermal-induced myofibrillar protein gels containing edible insects. ${ }^{1}$

\begin{tabular}{|c|c|c|c|c|c|c|}
\hline Treatments ${ }^{2}$ & Control & $\mathrm{T} 1$ & T2 & T3 & $\mathrm{T} 4$ & T5 \\
\hline \multicolumn{7}{|l|}{ Raw } \\
\hline $\mathrm{pH}$ & $6.13 \pm 0.02^{\mathrm{e}}$ & $6.24 \pm 0.01^{c}$ & $6.24 \pm 0.01^{c}$ & $6.35 \pm 0.01^{b}$ & $6.51 \pm 0.02^{\mathrm{a}}$ & $6.20 \pm 0.02^{d}$ \\
\hline $\mathrm{CIE} \mathrm{L}^{*}$ & $59.75 \pm 0.73^{a}$ & $52.30 \pm 2.19 b c$ & $53.38 \pm 2.88^{b}$ & $48.78 \pm 0.79^{c}$ & $58.32 \pm 1.27^{a}$ & $43.15 \pm 4.07^{d}$ \\
\hline $\mathrm{CIE} a^{*}$ & $-1.50 \pm 0.12^{f}$ & $0.15 \pm 0.17^{d}$ & $3.05 \pm 0.12^{a}$ & $1.20 \pm 0.06^{c}$ & $-0.42 \pm 0.08^{\mathrm{e}}$ & $2.71 \pm 0.19^{b}$ \\
\hline $\mathrm{CIE} \mathrm{b*}$ & $1.93 \pm 0.28^{e}$ & $8.38 \pm 0.61^{c}$ & $17.53 \pm 1.48^{\mathrm{a}}$ & $10.92 \pm 0.56^{b}$ & $5.51 \pm 0.45^{d}$ & $12.01 \pm 5.15^{b}$ \\
\hline \multicolumn{7}{|l|}{ Heated } \\
\hline $\mathrm{pH}$ & $6.20 \pm 0.01^{f}$ & $6.29 \pm 0.01^{\mathrm{e}}$ & $6.30 \pm 0.01^{d}$ & $6.56 \pm 0.01^{b}$ & $6.59 \pm 0.01^{a}$ & $6.33 \pm 0.01^{c}$ \\
\hline $\mathrm{CIE} \mathrm{L*}$ & $80.56 \pm 1.09^{a}$ & $69.98 \pm 1.65^{c}$ & $63.11 \pm 0.52^{d}$ & $58.46 \pm 0.31^{e}$ & $75.28 \pm 0.50^{b}$ & $59.18 \pm 2.13^{e}$ \\
\hline $\mathrm{CIE} a^{*}$ & $2.92 \pm 0.06^{\mathrm{e}}$ & $0.36 \pm 0.95^{c}$ & $4.47 \pm 0.47^{a}$ & $1.71 \pm 0.04^{b}$ & $0.85 \pm 0.29^{d}$ & $4.93 \pm 1.09^{a}$ \\
\hline CIE b* & $3.94 \pm 0.36^{d}$ & $12.79 \pm 2.75^{b}$ & $20.04 \pm 0.93^{a}$ & $13.28 \pm 0.24^{b}$ & $7.50 \pm 0.45^{c}$ & $17.19 \pm 2.73^{a}$ \\
\hline WHC(\%) & $56.50 \pm 2.07^{b}$ & $58.38 \pm 1.76^{b}$ & $52.64 \pm 2.64^{c}$ & $56.91 \pm 1.68^{b}$ & $62.59 \pm 1.01^{\mathrm{a}}$ & $55.72 \pm 1.64^{\text {bc }}$ \\
\hline
\end{tabular}

\footnotetext{
${ }^{1}$ All values are presented as the mean \pm standard deviation of three replicates $(n=3)$. Means within a row with different letters are significantly different $(P<0.05)$. ${ }^{2}$ Control = gel without edible insect; $\mathrm{T} 1=1 \%$ Tenebrio molitor larvae; $\mathrm{T} 2=1 \%$ Protaetia brevitarsis larvae; $\mathrm{T} 3=1 \%$ Allomyrina dichotoma larvae; $\mathrm{T} 4=1 \%$ Gryllus bimaculatus adult; $\mathrm{T} 5=1 \%$ Oxyachinensis sinuosa adult.
}

2021a). Melanin is a major insect pigment produced by biosynthesis pathways (Wittkopp and Beldade, 2009).

The WHC of the thermal-induced myofibrillar gels ranged from 52.64-62.59\%. The WHC of the myofibrillar gel containing T4 samples was higher than that of the other samples $(P<0.05)$. G. bimaculatus contains a large amount of chitin (Chae et al., 2018), which is known to have a high WHC (Chang et al., 1994). According to Choi et al. (2011), gel formation occurs during protein denaturation followed by irreversible aggregation, and the thermal-induced myofibrillar protein gel forms a three-dimensional network in which water is trapped. Although WHC of treatments was higher $(P<0.05)$ or similar $(P>0.05)$ with control, WHC of T2 was lower than control $(P<0.05)$. It might be due to poor insect-protein interaction with other protein and water than porcine myofibrillar protein (Scholliers et al., 2020). Thus, the high WHC of myofibrillar gels containing edible insects may be advantageous in the application of various products by improving the processing potential of insect products.

\section{Texture profile analysis}

The texture profiles of the thermal-induced myofibrillar gels containing five different edible insect species exhibited considerable differences among treatments (Table 2). The hardness, cohesiveness, gumminess, and chewiness of the control thermal-induced myofibrillar gel (without edible insects) were higher $(P<0.05)$ than those of the thermal-induced myofibrillar gels containing edible insects, except for myofibrillar gel containing T4. The hardness, cohesiveness, gumminess, and chewiness of the thermal-induced myofibrillar gel containing T4 were the highest $(P<0.05)$. The springiness of the thermalinduced myofibrillar gels ranged from 0.84-0.96, and that of the thermal-induced myofibrillar gel containing $P$. brevitarsis $(\mathrm{T} 2)$ was the lowest $(P<0.05)$. Kim et al.

Table 2. Texture profile analysis of thermal-induced myofibrillar protein gels containing edible insects. ${ }^{1}$

\begin{tabular}{|c|c|c|c|c|c|c|}
\hline Treatments $^{2}$ & Control & $\mathrm{T} 1$ & $\mathrm{~T} 2$ & T3 & $\mathrm{T} 4$ & T5 \\
\hline Hardness (g) & $40.59 \pm 1.24^{b}$ & $28.64 \pm 1.31^{d}$ & $17.31 \pm 1.26^{\mathrm{e}}$ & $32.65 \pm 1.78^{c}$ & $48.68 \pm 1.15^{a}$ & $17.05 \pm 1.32^{\mathrm{e}}$ \\
\hline Springiness & $0.96 \pm 0.03^{a}$ & $0.92 \pm 0.05^{b}$ & $0.84 \pm 0.04^{c}$ & $0.92 \pm 0.05^{b}$ & $0.95 \pm 0.05^{a}$ & $0.93 \pm 0.04^{a b}$ \\
\hline Cohesiveness & $0.43 \pm 0.01^{b}$ & $0.39 \pm 0.01^{c}$ & $0.36 \pm 0.03^{d}$ & $0.37 \pm 0.01^{d}$ & $0.47 \pm 0.01^{a}$ & $0.39 \pm 0.02^{c}$ \\
\hline Gumminess (g) & $17.27 \pm 0.38^{b}$ & $11.19 \pm 0.61^{c}$ & $6.27 \pm 0.67^{d}$ & $12.17 \pm 0.83^{c}$ & $22.70 \pm 0.64^{a}$ & $6.68 \pm 0.54^{d}$ \\
\hline Chewiness (g) & $16.55 \pm 0.56^{\mathrm{b}}$ & $10.32 \pm 0.25^{c}$ & $5.23 \pm 0.62^{\mathrm{e}}$ & $11.18 \pm 1.22^{c}$ & $21.58 \pm 0.96^{\mathrm{a}}$ & $6.19 \pm 0.56^{d}$ \\
\hline
\end{tabular}


(2021b) reported that the hardness of a gel containing A. dichotoma was higher than that of gels containing $T$. molitor and $P$. brevitarsis, and significant differences in texture profiles were confirmed in gels prepared only using edible insect proteins. Thus, it was confirmed that the structure and physical properties of the gel are affected by the insect protein, which is similar to the results of this study. According to Choi et al. (2011), the texture profile of thermal-induced gels is affected by the protein concentration and protein interaction. Westphalen et al. (2006) reported that the texture profiles of thermal-induced gel containing porcine myofibrillar protein is affected by muscle type, and it contributes to the texture profile which is also affected by the gelling capacity of protein interaction. Nuckles et al. (1991) noted that the gelation of thermalinduced myofibrillar gel is one of the most substantial functional properties of meat emulsion products due to its desirable textural properties. Thus, it is possible that texture profiles of thermal-induced gels may be attributed to the interaction between porcine myofibrillar protein and edible insect protein, and it may expand its utilisation as an edible insect protein.

\section{Differential scanning calorimetry}

Differences and changes in the structural characteristics of proteins can be induced by heating; denaturation temperature and enthalpy can be detected via DSC (Kazemi et al., 2011; Quinn et al., 1980). Generally, myosin and actin are denatured at approximately $55^{\circ} \mathrm{C}$ and $78-80^{\circ} \mathrm{C}$, respectively (Kazemi et al., 2011). Denaturation of the control gel started at approximately $52.43^{\circ} \mathrm{C}$ and ended at approximately $76.11{ }^{\circ} \mathrm{C}$ (Table 3 ). Therefore, the control gel followed the general thermal characteristics of myofibrillar protein. Thermal properties of proteins are affected by the type of protein, protein hydration, hydrophobic residue, hydrophilic residue, and added ingredients (Parniakov et al., 2018; Quinn et al., 1980). Therefore, protein-protein interactions, protein-water interactions, and protein residues may change with the addition of edible insects. All treatments except for $\mathrm{T} 4$ had higher peak temperatures than those of the control $(P<0.05)$ and a similar $(P>0.05)$ or lower $(P<0.05)$ enthalpy $(\Delta \mathrm{H})$, which is the energy required for denaturation. When proteins are heated, highly denatured proteins require a lower enthalpy than that required by proteins denatured to a lower extent (Kazemi et al., 2011). These results showed that the thermal properties of myofibrillar protein can be affected by the addition of edible insects and by the interaction with myofibrillar protein and processed insects. However, a similar peak temperature between the control and T4 was observed $(P>0.05)$, and T4 had a higher enthalpy than that of the control $(P<0.05)$. This higher value of enthalpy indicates a more complex protein structure. Therefore, T4 may form a more compact gel than that formed by other treatments.

\section{Sodium dodecyl sulphate-polyacrylamide gel electrophoresis}

The molecular weight distribution of edible insects and myofibrillar proteins of various edible insects is shown in Figure 1. When focused on protein distribution of edible insects, their patterns were different by species. The major bands of $T$. molitor were observed below $15 \mathrm{kDa}$ before and after reducing. High intense protein bands were observed between 75 and $100 \mathrm{kDa}$ in P. brevitarsis and the difference between reducing and non-reducing was slight; protein bands under $20 \mathrm{kDa}$ was observed after reducing. In $A$. dichotoma, protein band above $250 \mathrm{kDa}$ was observed before reducing, but this band was disappeared after reducing. The clear changes after reducing in protein bands were observed in G. bimaculatus compared with other species. The protein bands between 75 and $150 \mathrm{kDa}$ was reduced to $37-50 \mathrm{kDa}$ by mercaptoethanol and this protein molecular weight was similar with actin component in meat (Choi et al., 2011). O. sinuosa had the highest intensity above $250 \mathrm{kDa}$ and disulphide bonds induced by heating between proteins might be a reason of increased molecular weight because novel bands were observed between 100-250 $\mathrm{kDa}$. Although the exact protein by molecular weight was not identified in this study, this difference might affect gel properties of myofibrillar protein due to changes in various

Table 3. Differential scanning calorimetry of thermal-induced myofibrillar protein gels containing edible insects. ${ }^{1}$

\begin{tabular}{lllllll} 
Treatments $^{2}$ & Control & T1 & T2 & T3 & T4 & T5 \\
Onset temperature $\left({ }^{\circ} \mathrm{C}\right)$ & $52.43 \pm 0.78^{\mathrm{ab}}$ & $54.40 \pm 3.35^{\mathrm{ab}}$ & $54.88 \pm 1.73^{\mathrm{a}}$ & $53.69 \pm 0.83^{\mathrm{ab}}$ & $50.50 \pm 1.05^{\mathrm{b}}$ & $52.74 \pm 0.35^{\mathrm{ab}}$ \\
Peak temperature $\left({ }^{\circ} \mathrm{C}\right)$ & $66.52 \pm 0.52^{\mathrm{b}}$ & $71.40 \pm 0.53^{\mathrm{a}}$ & $71.21 \pm 0.56^{\mathrm{a}}$ & $70.27 \pm 0.71^{\mathrm{a}}$ & $66.66 \pm 1.29^{\mathrm{b}}$ & $69.90 \pm 0.58^{\mathrm{a}}$ \\
End temperature $\left({ }^{\circ} \mathrm{C}\right)$ & $76.11 \pm 0.65^{\mathrm{b}}$ & $79.40 \pm 1.21^{\mathrm{a}}$ & $78.71 \pm 1.48^{\mathrm{a}}$ & $77.89 \pm 0.52^{\mathrm{ab}}$ & $78.54 \pm 0.81^{\mathrm{a}}$ & $78.08 \pm 0.53^{\mathrm{ab}}$ \\
Delta $\mathrm{H}(\mathrm{J} / \mathrm{g})$ & $0.60 \pm 0.01^{\mathrm{b}}$ & $0.52 \pm 0.09^{\mathrm{bc}}$ & $0.47 \pm 0.03^{\mathrm{c}}$ & $0.48 \pm 0.03^{\mathrm{bc}}$ & $0.97 \pm 0.04^{\mathrm{a}}$ & $0.52 \pm 0.0 .05^{\mathrm{bc}}$ \\
\hline
\end{tabular}

${ }^{1}$ All values are presented as the mean \pm standard deviation of three replicates $(n=3)$. Values within a row with different letters are significantly different $(P<0.05)$. ${ }^{2}$ Control = gel without edible insect; $\mathrm{T} 1=1 \%$ Tenebrio molitor larvae; $\mathrm{T} 2=1 \%$ Protaetia brevitarsis larvae; $\mathrm{T} 3=1 \%$ Allomyrina dichotoma larvae; $\mathrm{T} 4=1 \%$ Gryllus bimaculatus adult; $T 5=1 \%$ Oxyachinensis sinuosa adult. 

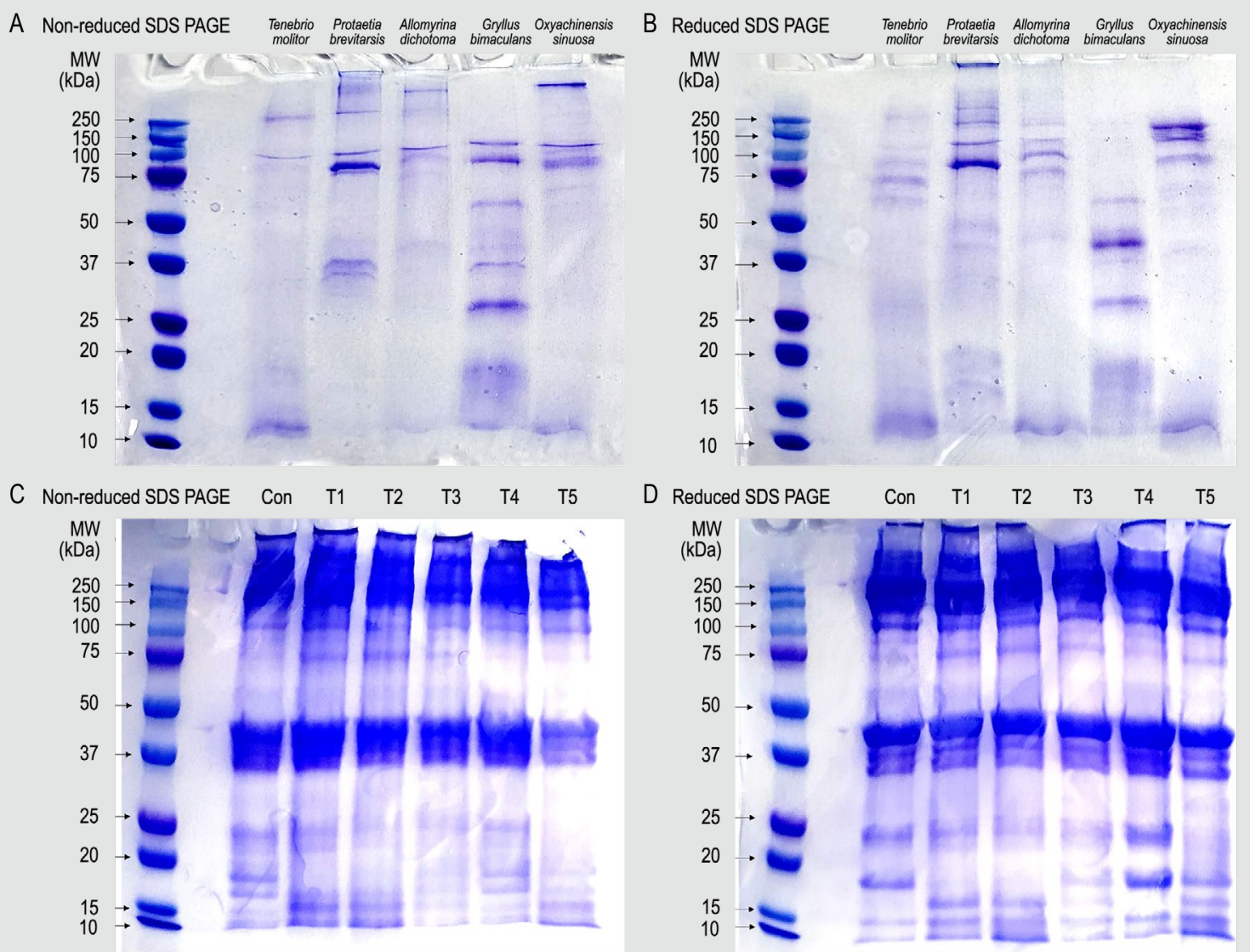

Figure 1. Protein bands obtained using non-reduced and reduced SDS-PAGE for edible insects (A and B) and thermal-induced myofibrillar protein gels containing edible insects (C and D). Con, gel without edible insect; T1, 1\% Tenebrio molitor larvae; T2, $1 \%$ Protaetia brevitarsis larvae; T3, 1\% Allomyrina dichotoma larvae; T4, 1\% Gryllus bimaculatus adult.; T5, 1\% 0xyachinensis sinuosa adult.; SDS-PAGE = sodium dodecyl sulphate-polyacrylamide gel electrophoresis.

interaction (ionic bonds, hydrophilic bonds, hydrophobic interaction, and disulphide bonds) between proteins (Zayas, 2012).

Myosin heavy chain (205 kDa), actin (45 kDa), tropomyosin (34 kDa), troponin-1 (21 kDa), and myosin light chain $(22,18$, and $16 \mathrm{kDa})$ are composed of general myofibrillar proteins (Choi et al., 2011). The interaction and ratio between myosin $(205 \mathrm{kDa})$ and actin $(45 \mathrm{kDa})$ is critical when forming compact gel structure (Samejima et al., 1981). When the molecular distribution was compared using non-reduced SDS-PAGE, the treatment groups showed different distributions from that of the control. In addition, high intensity around molecular weight of abovementioned proteins in treatments also might be due to myofibrillar protein. Large bands between 75 and $100 \mathrm{kDa}$ were observed for T1, T2, and T3, and large protein bands of approximately $10 \mathrm{kDa}$ were also observed for $\mathrm{T} 1$ and $\mathrm{T} 2$. After the reduction of disulphide bonds, protein bands were separated more clearly because almost heat-induced protein interactions linked by disulphide bonds (Yasui et al., 1982). Protein bands of control and treatments that were above 250
$\mathrm{kDa}$ and between 37 and $50 \mathrm{kDa}$ appeared faint. Thus, these fainted bands could explain that myosin and actin proteins were interacted with disulphide bonds. When compared to the patterns of the control and treatments, new protein patterns except for T4 samples were observed, and certain protein bands appeared faint or were not observed. Protein bands observed between 15 and $20 \mathrm{kDa}$ for the control were not observed for $\mathrm{T} 1$ and $\mathrm{T} 2$, and protein bands at 20 and $25 \mathrm{kDa}$ appeared faint. In contrast, protein bands at $75 \mathrm{kDa}$ were thicker than those of the control. Although protein bands of $P$. brevitarsis between 10-15 kDa was not observed before reducing, novel protein bands were observed between 10-15 kDa after reducing. In addition, protein bands observed for the control were not observed for the treatments, especially myosin light chain. In general, insects are processed without any separation of components such as meat, fat, organs, and blood, even, digestive enzymes because of their small body size. Therefore, various components obtained from insects could affect myofibril protein interaction such as binding inhibiting or degradation by enzymes during manufacturing. These changes can affect molecular weights of proteins and the 
difference in SDS-PAGE could be occurred (Vasilescu et al., 2004). Therefore, various uncharacterised components in edible insects can bind or lose protein interactions and affect molecular weights. The protein molecular weight distribution of T4 was similar to that of the control, and the band intensity was strong. When the hardness of the protein gel was observed, $\mathrm{T} 4 \mathrm{had}$ the highest hardness value compared to that of other treatments $(P<0.05)$. Therefore, the addition of $G$. bimaculatus may enhance myofibrillar protein interaction, and changes in protein patterns based on insect composition may negatively affect the formation of a compact gel.

\section{Rheological properties}

The rheological properties of myofibrillar proteins containing five different edible insect species are shown in Figure 2. The changes in viscosity of all samples when shear stress was applied at $25^{\circ} \mathrm{C}$ are shown in Figure 2A. The viscosity of all samples, including the control, decreased as the shear rate increased, indicating a shear-thinning behaviour. A minor difference between the viscosities of the samples was observed. This indicates that the addition of edible insect proteins to myofibrillar protein derived from lean meat did not affect the apparent viscosity based on the shear rate. In general, most food materials and polymer suspensions are shear-thinning fluids. Likewise, the flow behaviour index $(n)$ of the control, T1, T2, T3, T4, and T5 samples was lesser than $1(0.150 \pm 0.015,0.166 \pm 0.010$, $0.104 \pm 0.039,0.144 \pm 0.032,0.143 \pm 0.013$, and $0.106 \pm 0.002$, respectively), indicating non-Newtonian and pseudoplastic behaviour (Gomathy et al., 2015). However, none of the samples flowed until the shear stress reached specific values (yield stress), and the samples exhibited solid-like behaviour below the values (Figure 2B). When flow curves do not pass through the origin, this implies the presence of yield stress (Štreimikyte et al., 2020). The yield stress values of the control, T1, T2, T3, T4, and T5 samples were $30.1 \pm 1.5$, $25.4 \pm 0.2,24.7 \pm 0.1,24.9 \pm 0.9,29.0 \pm 1.7$, and $26.6 \pm 0.3 \mathrm{~Pa}$, respectively. The control and T4 samples began flowing (fluid behaviour) at a higher shear stress than that of other samples $(P<0.05)$. This was in agreement with the hardness results of the samples. These rheological properties indicate that myofibrillar protein gels containing five different insect species represent Hershel-Bulkley fluids; they sustained their initial structure below the yield stress, and their viscosities decreased as the shear rate increased. However, there were differences between the control and treatment samples. The shear stress of the control sample steadily increased as the shear rate increased; however, the slope of the curve with the shear rate increased. In contrast, the treatment samples exhibited complex patterns. At low shear rates, the shear stresses of the treated samples increased more sharply than those of the control sample
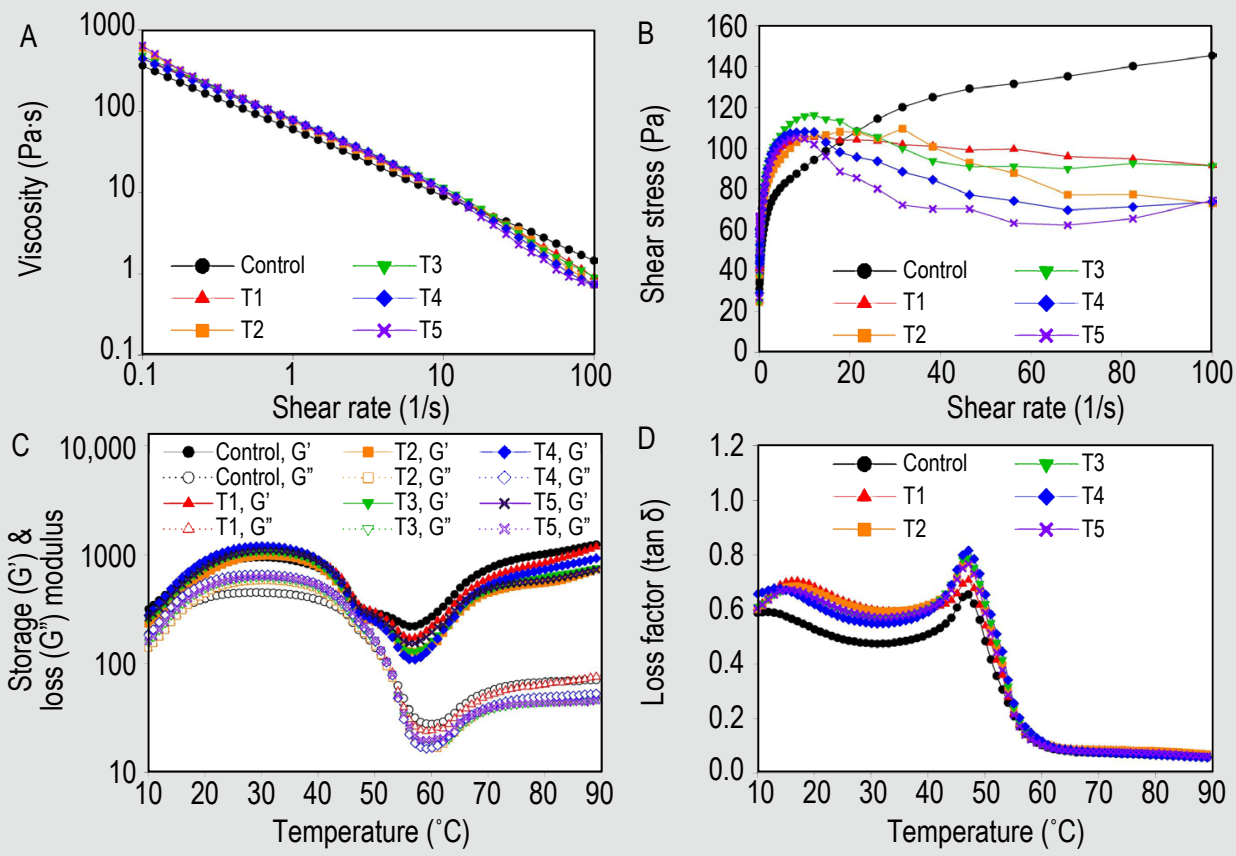

Figure 2. Rheological properties of the myofibrillar protein gels containing edible insects. Variations in (A) viscosity and (B) shear stress are presented as a function of shear rate. Variations in (C) storage ( $\left.G^{\prime}\right)$ and loss (G') modulus, and variations in (D) loss factor (tan $\delta$ ) are presented as a function of temperature. Control, gel without edible insect; T1, 1\% Tenebrio molitor larvae; T2, $1 \%$ Protaetia brevitarsis larvae; T3, 1\% Allomyrina dichotoma larvae; T4, 1\% Gryllus bimaculatus adult; $\mathrm{T}, 1 \%$ Oxyachinensis sinuosa adult. 
and were maintained or slightly decreased at high shear rates. In addition, consistency coefficient $(K)$ of myofibrillar proteins with edible insect species $(70.03 \pm 1.43,74.78 \pm 1.89$, $75.16 \pm 1.56,70.42 \pm 6.38$, and $73.05 \pm 4.43 \mathrm{~Pa}^{\mathrm{n}} \mathrm{s}^{\mathrm{n}}$, respectively) were higher than $K$ of the control sample $(61.96 \pm 3.78$ $\left.\mathrm{Pa} " \mathrm{~s}^{\mathrm{n}}\right)$. These differences $(P<0.05)$ may be due to changes in protein-protein interactions due to the increase in the myosin light chain content of edible insect proteins (section 3.4). The changes in G', G', and loss factor ( $\left.\tan \delta=G^{\prime} / G^{\prime}\right)$ as a function of temperature are presented in Figure $2 \mathrm{C}$ and 2D). All samples showed similar trends with increasing temperature from 10 to $90^{\circ} \mathrm{C}$. The apparent onset of gelation occurred at approximately $40{ }^{\circ} \mathrm{C}$. During the heating process, myosin loses its $\alpha$-helix structure, followed by intermolecular association and aggregation, stabilisation of covalent (disulphides) and noncovalent interactions, and development of a rigid structure (Zayas, 2012). The G' and $G^{\prime}$ values decreased in the temperature range of $40-60^{\circ} \mathrm{C}$ and increased above $60^{\circ} \mathrm{C}$ due to the formation of a rigid structure. As shown in Figure 2D, the loss factor of control sample was slightly lower than the values of other samples containing edible insect proteins in temperature range of 10 to $40{ }^{\circ} \mathrm{C}(P<0.05)$. The loss factors of each sample at $40{ }^{\circ} \mathrm{C}$ were $0.509 \pm 0.021,0.604 \pm 0.006,0.618 \pm 0.005$, $0.607 \pm 0.004,0.592 \pm 0.003$, and $0.604 \pm 0.002$, respectively. Gel formation in meat products is generally related to the gel-forming properties of myosin and actomyosin (Zayas, 2012). Samejima et al. (1981) reported that myosin heavy chains are mainly responsible for the thermal gelation of myosin, and the rigidity of the gel during heating is affected by the myosin/actin ratio. Yasui et al. (1982) reported that the maximum increase in gel rigidity is obtained at a myosin-to-actin ratio of 15 . In addition, the loss factor of all samples reached the highest value at approximately $47^{\circ} \mathrm{C}$ and then decreased sharply until temperature increased to $60^{\circ} \mathrm{C}$. The loss factors of each sample at the end of the temperature $\left(90^{\circ} \mathrm{C}\right)$ sweeps were $0.056 \pm 0.003,0.063 \pm 0.002$, $0.069 \pm 0.001,0.060 \pm 0.001,0.055 \pm 0.004$, and $0.060 \pm 0.001$, respectively. The value of $\tan \delta$, which is smaller than 1 , indicates a solid-like behaviour (Lee et al., 2018). Thus, the very low values of $\tan \delta$ at high temperatures indicate that the network reached a high degree of development.

\section{Conclusions}

The study on thermal-induced protein gels showed that the interaction between porcine myofibril protein and edible insect species considerably influences thermal stability and rheological properties. The thermal-induced myofibrillar protein gel was prepared from five different edible insect species (larvae: T. molitor, P. brevitarsis, and A. dichotoma; adults: G. bimaculatus, and $O$. sinuosa). The gels showed different thermal stabilities and rheological properties depending on the edible insect species used. These results suggest that the thermal-induced myofibrillar protein gel prepared using G. bimaculatus protein resources may have excellent processing functionality. Furthermore, edible insect proteins can replace animal proteins and various protein resource foods.

\section{Acknowledgements}

This research was funded by the Main Research Program (E0211200-01) of the Korea Food Research Institute.

\section{Conflicts of interest}

The authors declare no conflicts of interest.

\section{References}

Bourne, M.C., Kenny, J.F. and Barnard, J., 1978. Computer-assisted readout of data from texture profile analysis curves 1 . Journal of Texture Studies 9: 481-494.

Chae, K.-S., Shin, C.-S. and Shin, W.-S., 2018. Characteristics of cricket (Gryllus bimaculatus) chitosan and chitosan-based nanoparticles. Food Science and Biotechnology 27: 631-639.

Chang, H.-J., Jeon, D.-W. and Lee, S.-R., 1994. In vitro study on the functionality in digestive tract of chitin and chitosan from crab shell. Korean Journal of Food Science and Technology 26: 348-354.

Cheng, J., Zhu, M. and Liu, X., 2020. Insight into the conformational and functional properties of myofibrillar protein modified by mulberry polyphenols. Food Chemistry 308: 125592.

Choi, Y.S., Choi, J.H., Han, D.J., Kim, H.Y., Lee, M.A., Kim, H.W., Jeong, J.Y. and Kim, C.J., 2011. Effects of rice bran fiber on heat-induced gel prepared with pork salt-soluble meat proteins in model system. Meat Science 88: 59-66.

Choi, Y.S., Kim, T.K., Choi, H.D., Park, J.D., Sung, J.M., Jeon, K.H., Paik, H.D. and Kim, Y.B., 2017. Optimization of replacing pork meat with yellow worm (Tenebrio molitor L.) for Frankfurters. Korean Journal of Food Science for Animal Resources 37: 617-625.

Gomathy, K., Thangavel, K., Balakrishnan, M. and Kasthuri, R., 2015. Effect of ohmic heating on the electrical conductivity, biochemical and rheological properties of papaya pulp. Journal of Food Process Engineering 38: 405-413.

Ham, Y.-K., Kim, S.-W., Song, D.-H., Kim, H.-W. and Kim, I.-S., 2021. Nutritional composition of white-spotted flower chafer (Protaetia brevitarsis) larvae produced from commercial insect farms in Korea. Food Science of Animal Resources 41: 416.

Kazemi, S., Ngadi, M.O. and Gariépy, C., 2011. Protein denaturation in pork longissimus muscle of different quality groups. Food and Bioprocess Technology 4: 102-106.

Kim, T.-K., Lee, M.H., Yong, H.I., Jung, S., Paik, H.-D., Jang, H.W. and Choi, Y.-S., 2020. Effect of interaction between mealworm protein and myofibrillar protein on the rheological properties and thermal stability of the prepared emulsion systems. Foods 9: 1443.

Kim, T.K., Lee, M.H., Yu, M.H., Yong, H.I., Jang, H.W., Jung, S. and Choi, Y.S., 2021b. Thermal stability and rheological properties of heat-induced gels prepared using edible insect proteins in a model system. LWT - Food Science and Technology 134: 110270. 
Kim, T.K., Yong, H.I., Jeong, C.H., Han, S.G., Kim, Y.B., Paik, H.D. and Choi, Y.S., 2019a. Technical functional properties of water- and salt-soluble proteins extracted from edible insects. Food Science of Animal Resources 39: 643-654.

Kim, T.-K., Yong, H.I., Jung, S., Sung, J.-M., Jang, H.W. and Choi, Y.S., 2021a. Physicochemical and textural properties of emulsions prepared from the larvae of the edible insects Tenebrio molitor, Allomyrina dichotoma, and Protaetia brevitarsis seulensis. Journal of Animal Science and Technology 63: 417-425.

Kim, T.K., Yong, H.I., Kim, Y.B., Kim, H.W. and Choi, Y.S., 2019b. Edible insects as a protein source: a review of public perception, processing technology, and research trends. Food Science of Animal Resources 39: 521-540.

Kocher, P. and Foegeding, E., 1993. Microcentrifuge-based method for measuring water-holding of protein gels. Journal of Food Science 58: 1040-1046.

Köhler, R., Kariuki, L., Lambert, C. and Biesalski, H., 2019. Protein, amino acid and mineral composition of some edible insects from Thailand. Journal of Asia-Pacific Entomology 22: 372-378.

Laemmli, U., 1970. SDS-page Laemmli method. Nature 227: 680-685.

Lee, M.H., Shin, G.H. and Park, H.J., 2018. Solid lipid nanoparticles loaded thermoresponsive pluronic-xanthan gum hydrogel as a transdermal delivery system. Journal of Applied Polymer Science 135: 46004 .

Li, K., Fu, L., Zhao, Y.-Y., Xue, S.-W., Wang, P., Xu, X.-L. and Bai, Y.$H ., 2020$. Use of high-intensity ultrasound to improve emulsifying properties of chicken myofibrillar protein and enhance the rheological properties and stability of the emulsion. Food Hydrocolloids 98: 105275.

McCord, A., Smyth, A. and O'Neill, E., 1998. Heat-induced gelation properties of salt-soluble muscle proteins as affected by non-meat proteins. Journal of Food Science 63: 580-583.

Nuckles, R., Smith, D. and Merkel, R., 1991. Properties of heat-induced gels from beef skeletal, heart, lung and spleen protein fractions. Journal of Food Science 56: 1165-1170.

Park, Y.-S., Choi, Y.-S., Hwang, K.-E., Kim, T.-K., Lee, C.-W., Shin, D.-M. and Han, S.G., 2017. Physicochemical properties of meat batter added with edible silkworm pupae (Bombyx mori) and transglutaminase. Korean Journal for Food Science of Animal Resources 37: 351.

Parniakov, O., Bals, O., Barba, F.J., Mykhailyk, V., Lebovka, N. and Vorobiev, E., 2018. Application of differential scanning calorimetry to estimate quality and nutritional properties of food products. Critical Reviews in Food Science and Nutrition 58: 362-385.
Quinn, J., Raymond, D. and Harwalkar, V., 1980. Differential scanning calorimetry of meat proteins as affected by processing treatment. Journal of Food Science 45: 1146-1149.

Samejima, K., Ishioroshi, M. and Yasui, T., 1981. Relative roles of the head and tail portions of the molecule in heat-induced gelation of myosin. Journal of Food Science 46: 1412-1418.

Scholliers, J., Steen, L. and Fraeye, I., 2020. Partial replacement of meat by superworm (Zophobas morio larvae) in cooked sausages: effect of heating temperature and insect: meat ratio on structure and physical stability. Innovative Food Science \& Emerging Technologies 66: 102535.

Štreimikytė, P., Keršienė, M., Eisinaitė, V., Jasutienė, I., Lesauskaitė, V., Damulevičienè, G., Knašienè, J. and Leskauskaitė, D., 2020. Formulating protein-based beverages for the dysphagia diets of the elderly: viscosity, protein quality, in vitro digestion, and consumers acceptability. Journal of the Science of Food and Agriculture 100: 3895-3901.

Vasilescu, J., Guo, X. and Kast, J., 2004. Identification of protein-protein interactions using in vivo cross-linking and mass spectrometry. Proteomics 4: 3845-3854.

Westphalen, A.D., Briggs, J.L. and Lonergan, S.M., 2006. Influence of muscle type on rheological properties of porcine myofibrillar protein during heat-induced gelation. Meat Science 72: 697-703.

Wittkopp, P.J. and Beldade, P., 2009. Development and evolution of insect pigmentation: genetic mechanisms and the potential consequences of pleiotropy. Seminars in Cell \& Developmental Biology 20: 65-71.

$\mathrm{Xu}, \mathrm{Y}$. and Xu, X., 2021. Modification of myofibrillar protein functional properties prepared by various strategies: a comprehensive review. Comprehensive Reviews in Food Science and Food Safety 20: 458500.

Yasui, T., Ishioroshi, M. and Samejima, K., 1982. Effect of actomyosin on heat-induced gelation of myosin. Agricultural and Biological Chemistry 46: 1049-1059.

Zayas, J.F., 2012. Functionality of proteins in food. Springer Science \& Business Media, Berlin, Germany.

Zhuang, X., Jiang, X., Zhou, H., Chen, Y., Zhao, Y., Yang, H. and Zhou, G., 2020. Insight into the mechanism of physicochemical influence by three polysaccharides on myofibrillar protein gelation. Carbohydrate Polymers 229: 115449. 
